\title{
Identification and quantitative estimation of a lignan in human and bovine semen
}

\author{
L. Dehennin, A. Reiffsteck, M. Jondet and M. Thibier*
}

Fondation de Recherche en Hormonologie, 67/77 boulevard Pasteur, 94260 Fresnes and 26 boulevard Brune, 75014 Paris and *INA Paris-Grignon, 78850 Thiverval-Grignon, France

\begin{abstract}
Summary. The lignan identified in human and bovine semen was trans 2,3bis( 3 '-hydroxybenzyl)- $\gamma$-butyrolactone. It was present in unconjugated and conjugated forms. Mean seminal plasma concentrations were always higher than the corresponding blood plasma levels (between 2.5 and 25 times higher), indicating an efficient clearance capacity of the male reproductive system.
\end{abstract}

\section{Introduction}

The occurrence of lignans, mainly trans 2,3 -bis( $3^{\prime}$-hydroxybenzyl)- $\gamma$-butyrolactone (enterolactone, Text-fig. 1), in urine, bile, faeces and plasma of human and other animal species (monkey, rat) has been extensively discussed (Setchell, Bull \& Adlercreutz, 1980; Setchell, Lawson, Axelson \& Adlercreutz, 1980; Setchell et al., $1981 \mathrm{a}, \mathrm{b})$. Simultaneously, Stitch et al. (1980) have shown enterolactone to have characteristic excretion patterns in ovulatory cycles and in pregnancy. Conjugation of lignans, mainly as glucuronides (Axelson \& Setchell, 1980), and evidence for an intestinal bacterial origin (Axelson \& Setchell, 1981; Setchell et al., 1981 c) have been reported.

We have investigated the concentrations of enterolactone in seminal fluid of men and bulls.

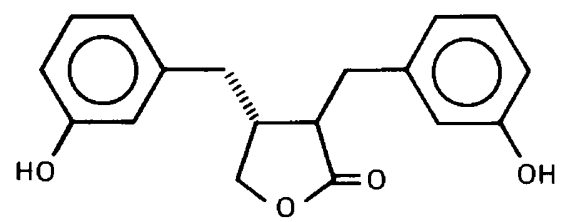

Text-fig. 1. The structure of trans 2,3-bis( $3^{\prime}$-hydroxybenzyl)- $\gamma$-butyrolactone (enterolactone).

\section{Materials and Methods}

\section{Blood and semen collection}

Ejaculates from 6 men were collected by masturbation after at least 3 days of abstinence. They were qualitatively and quantitatively evaluated by the criteria given by Jondet \& Tea (1981) and proven to have normal spermograms. Peripheral blood samples were taken the same day into vacuum tubes containing EDTA.

Four Montbéliarde bulls of about 1 year of age, fed for the previous 3 months on hay ( 10 $\mathrm{kg} /$ day) and concentrates $(4 \mathrm{~kg} /$ day $)$, were allowed to ejaculate weekly during 1 month. Ejaculates were collected into an artificial vagina and evaluated according to classical criteria, 
described previously by Thibier \& Colchen-Bourlaud (1972). Peripheral blood was withdrawn by jugular venepuncture into heparinized vacuum tubes.

All blood and semen samples were centrifuged $(3000 \mathrm{~g}, 10 \mathrm{~min})$ and the corresponding plasmas were stored at $-20^{\circ} \mathrm{C}$ until analysis.

\section{Synthetic enterolactone}

Enterolactone was synthesized according to Groen \& Leemhuis (1980), Cooley, Farrant, Kirk \& Wynn (1981) and Pelter, Satyanarayana \& Ward (1981). Pure reference compound was generously provided by Professor D. N. Kirk (Westfield College, London, U.K.) and by $\mathrm{Dr}$ M. B. Groen (Scientific Development Group, Organon B.V., Oss, The Netherlands).

\section{Deuterium labelled enterolactone}

Enterolactone was labelled by an exchange reaction similar to that described for oestrogens (Dehennin, Reiffsteck \& Scholler, 1980). Isotope composition measurements indicated a $\mathrm{d}_{0} / \mathrm{d}_{4}$ ratio of $0.9 \%$. A stock solution of $\left[{ }^{2} \mathrm{H}_{4}\right]$ enterolactone in pyridine (made anhydrous by refluxing on potassium hydroxide and fractional distillation) was prepared and the exact concentration was determined by gas chromatography. The stability of the labelled analogue was checked and proved to be sufficient for use as an internal standard.

\section{Synthetic enterolactone and human sperm motility}

A $5 \mu \mathrm{l}$ sample of a $1 \mu \mathrm{mol} / 1$ solution of enterolactone in phosphate saline buffer $(0.1 \mathrm{M}, \mathrm{pH}$ 7.4) was added to $5 \mu \mathrm{l}$ liquefied human semen. The percentage motile spermatozoa and sperm velocity were determined immediately, and at 1 and $2 \mathrm{~h}$ after mixing on a microscope slide.

\section{Extraction, purification and derivatization}

An amount of $\left[{ }^{2} \mathrm{H}_{4}\right]$ enterolactone (in $20 \mu \mathrm{l}$ ethanol) equivalent to the amount of natural compound was added to $1 \mathrm{ml}$ of blood or seminal plasma. After $30 \mathrm{~min}$ for equilibration, the sample was applied to an extraction column containing $1 \mathrm{~g}(7 \times 1 \mathrm{~cm})$ Extrelut (Merck, Darmstadt, West Germany) and soaked for $20 \mathrm{~min}$. Elution with $5 \mathrm{ml}$ diethyl ether gave, after evaporation, an extract which was applied to a column $(5 \times 0.4 \mathrm{~cm})$ of Sephadex LH-20 (Pharmacia Fine Chemicals, Uppsala, Sweden) swollen in benzene-ethanol $(85: 15, \mathrm{v} / \mathrm{v})$. The first $3 \mathrm{ml}$ of eluant were discarded and enterolactone was eluted in the next $2.5 \mathrm{ml}$. Evaporation of the solvent and derivatization with $\mathrm{N}, \mathrm{O}$-bis (trimethylsilyl)-trifluoroacetamide containing $5 \%$ trimethylchlorosilane, in dry pyridine, yielded the corresponding trimethylsilyl ethers (TMS).

An enzymic hydrolysis step with Helix pomatia digestive juice was included, prior to the addition of $\left[{ }^{2} \mathrm{H}_{4}\right]$ enterolactone, when total enterolactone concentrations were determined. Blood or seminal plasma samples $(1 \mathrm{ml})$ were diluted up to $10 \mathrm{ml}$ with acetate buffer $(0.2 \mathrm{M}, \mathrm{pH}=5.2)$ and incubated overnight at $37^{\circ} \mathrm{C}$ with $10^{3} \beta$-glucuronidase units and $10^{4}$ sulphatase units. The mixture was brought to neutrality, diluted up to $20 \mathrm{ml}$ with water and extracted with $20 \mathrm{ml}$ diethyl ether after soaking on a column containing $10 \mathrm{~g}$ Extrelut $(6 \times 3 \mathrm{~cm})$. Further treatment was identical to that described for unconjugated enterolactone.

\section{Gas chromatography-mass spectrometry ( $G C-M S)$}

GC-MS was performed on a glass capillary column $(25 \times 0.3 \mathrm{~mm})$ deactivated by persilylation and statically coated with OV-73 stationary phase. The column, fitted to an all-glass solid injection system, was operated at $230^{\circ} \mathrm{C}$ under $10^{5} \mathrm{~Pa}$ helium pressure and 
directly coupled to a quadrupole mass spectrometer (Nermag, Rueil-Malmaison, France). Electron impact spectra were obtained under normal operating conditions and selected ion monitoring was performed on the molecular ions $\left(\mathrm{M}^{+}\right)$of enterolactone-TMS $\left(\mathrm{M}^{+}, 442\right)$ and $\left[{ }^{2} \mathrm{H}_{4}\right.$ ]enterolactone-TMS $\left(\mathrm{M}^{+}, 446\right)$.

\section{Quantitative analysis}

Quantitative determinations were made according to the isotope dilution principle outlined previously (Dehennin, Reiffsteck, Scholler, Cohen \& Bizollon, 1980). Intra-assay variability was assessed on duplicate measurements which had relative standard deviations between 3 and $4 \%$.

\section{Results}

The identification of enterolactone in seminal fluid was based on the comparison of the mass spectra of underivatized and seminal compound, which revealed complete identity with prominent peaks at mass-to-charge ratios $(\mathrm{m} / \mathrm{z})$ of $298\left(\mathbf{M}^{+}, 8 \cdot 0 \%\right), 191(7.9 \%), 133(15 \cdot 2 \%)$, $107(100 \%)$ and $106(54.5 \%)$. The same close similarity was observed for the TMS derivative with characteristic peaks at $\mathrm{m} / \mathrm{z} 442\left(\mathrm{M}^{+}, 13 \cdot 2 \%\right), 263(6 \cdot 6 \%), 180(100 \%)$, and $73(84 \cdot 2 \%)$. A second identification criterion was the nearly identical chromatographic behaviour of enterolactone-TMS and its deuterated isotopomer which had, as could be expected for deuterium-labelled compounds, a slightly shorter retention index ( $\mathrm{I}_{230}^{\text {Ov-73 }}=2845$ for enterolactone-TMS and 2842 for $\left[{ }^{2} \mathrm{H}_{4}\right.$ ]enterolactone-TMS).

Seminal plasma and corresponding blood plasma levels are shown in Table 1. Total enterolactone concentrations should be considered less accurate than the unconjugated ones owing to possible incompleteness of the enzymic hydrolysis which could not be corrected by the use of an unconjugated labelled analogue.

Table 1. Concentrations $(\mathrm{nmol} / \mathrm{l})$ of enterolactone in seminal and blood plasma of normal men and bulls

\begin{tabular}{llccrrc}
\hline & & \multicolumn{2}{c}{ Men $(\mathrm{N}=6)$} & & \multicolumn{2}{c}{ Bulls $(\mathrm{N}=4)$} \\
\cline { 3 - 4 } \cline { 6 - 7 } & Enterolactone & Mean & Range & & Mean & Range \\
\hline \multirow{2}{*}{ Semen } & Unconjugated & 43 & $8 \cdot 0-127$ & 604 & $560-651$ \\
& Total & 183 & $63-557$ & 3200 & $3100-3300$ \\
\hline \multirow{2}{*}{ Blood } & Unconjugated & $14 \cdot 3$ & $10 \cdot 3-21$ & & 24 & $21-27$ \\
& Total & 73 & $37-127$ & & 228 & $198-258$ \\
\hline
\end{tabular}

There were no changes in the percentage motile spermatozoa or sperm motility of human ejaculates mixed with $1 \mu \mathrm{mol} / 1$ concentrations of synthetic enterolactone.

No immunological cross-reactivity could be assessed with an antiserum raised against oestrone-17-carboxymethyl-BSA cojugate in the rabbit and which is currently used for oestradiol-17 $\beta$ determinations by radioimmunoassay (Castanier \& Scholler, 1970).

Attempts to identify a second lignan, 2,3-bis(3'-hydroxybenzyl)-butane-1,4-diol, were unsuccessful.

\section{Discussion}

Enterolactone was detected during our investigations on the identification and the quantitative determination of seminal oestrogens by isotope dilution-mass spectrometry (Reiffsteck, 
Dehennin \& Scholler, 1981). The aromatic structure confers on enterolactone some chromatographic properties similar to those of oestrogens. No oestrogen-like action on mouse uterine weight could however be detected with enterolactone doses up to $67 \mu \mathrm{mol} / \mathrm{kg}$ body weight (Setchell et al., 1981c).

Bacteriological studies have suggested that Clostridia from intestinal microflora may be the principal source of enterolactone in man (Setchell et al., 1981c). According to Adlercreutz et al. (1981) and M. B. Groen (personal communication), enterolactone would be a metabolite of lignin from the fibrous constituents of the diet. These suggestions are corroborated by the high enterolactone levels and the limited concentration ranges found in bovine semen and blood. Indeed, cattle daily consume large amounts of lignin present in grass or forage (Harkin, 1973) and the rumen contains huge numbers $\left(10^{5}-10^{6}\right.$ per ml rumen content) of Clostridium lochheadii and Clostridium longisporum (Hungate, 1966). It should also be taken into account that the bovine semen and blood concentration ranges of enterolactone are related here to their strictly similar diet.

In human semen, and to a lesser degree also in blood, enterolactone levels were considerably lower. There was a high inter-individual variability which can, to some extent, be related to the variety of the human diet.

The ratio of unconjugated to conjugated enterolactone from semen and blood is largely in favour of the latter, but the proportion of unconjugated compound is significantly higher than that which has been observed in urine of the human male (Axelson \& Setchell, 1980).

It therefore seems, if the exogenous origin is confirmed, that enterolactone readily passes into the blood stream by enterohepatic circulation (Axelson \& Setchell, 1981; Setchell et al., 1981c). Eiler \& Graves (1977, 1981) and Graves \& Eiler (1979) have demonstrated the possibility of a rapid transfer of exogenous oestradiol-17 $\beta$, cortisol, testosterone and progesterone from the bovine circulatory system to the accessory sex glands and to semen at ejaculation. The clearance capacity of the male reproductive system might be a plausible explanation for the occurrence of enterolactone in semen.

Furthermore, high concentrations of enterolactone, such as those found in cattle, do not seem to be detrimental to semen output and qualitative traits, or to fertility. The bulls from which samples were collected were quite representative of the population with average semen quality and conception rate, similar to those reported by Abdel Malak \& Thibier (1982). However, this lignan could affect fertility after passing to the female genital tract during coitus, although possible physiological implications of enterolactone seem controversial. Many plant lignans are known to have antimitotic activity (Hartwell, 1976), while some clostridia are able to synthesize aromatic compounds which might be potentially carcinogenic (Goddard \& Hill, 1972).

We thank J. Dubois and P. Salvador for efficient technical aid.

\section{References}

Abdel Malak, G. \& Thibier, M. (1982) Plasma LH and testosterone responses to synthetic gonadotrophinreleasing hormone (GnRH) or dexamethasoneGnRH combined treatment and their relationship to semen output in bulls. J. Reprod. Fert. 64, 107113.

Adlercreutz, H., Fotsis, T., Heikkinen, R., Dwyer, J.T., Goldin, B.R., Gorbach, S.L., Lawson, A.M. \& Setchell, K.D.R. (1981) Diet and urinary excretion of lignans in female subjects. Med. Biol. 59, 259-261.

Axelson, M. \& Setchell, K.D.R. (1980) Conjugation of lignans in human urine. FEBS Lett. 122, 49-53.
Axelson, M. \& Setchell, K.D.R. (1981) The excretion of lignans in rats-evidence for an intestinal bacterial source for this new group of compounds. FEBS Lett. 123, 337-342.

Castanier, M. \& Scholler, R. (1970) Dosage radioimmunologique de l'estrone et de l'estradiol-17及 plasmatiques. C. r. hebd. Séanc. Acad. Sci. Paris 271, 1787-1789.

Cooley, G., Farrant, R.D., Kirk, D.N. \& Wynn, S. (1981) Chemical synthesis of the first lignans to be found in humans and animals. Tetrahedron Lett. 22 , 349-350. 
Dehennin, L., Reiffsteck, A., Scholler, R., Cohen, R. \& Bizollon, Ch.A. (1980) Isotope dilution-mass spectrometry: applications in the quality control of radioimmunoassay of steroid hormones. Eur. $J$. Mass Spectrom. 1, 97-98.

Dehennin, L., Reifisteck, A. \& Scholler, R. (1980) Simple methods for the synthesis of twenty different, highly enriched deuterium labelled steroids, suitable as internal standards for isotope dilution-mass spectrometry. Biomed. Mass Spectrom. 7, 493-499.

Eiler, H. \& Graves, C.N. (1977) Oestrogen content of semen and the effect of exogenous oestradiol-17 $\beta$ on the oestrogen and androgen concentration in semen and blood plasma of bulls. J. Reprod. Fert. 50, 17-21.

Eiler, H. \& Graves, C.N. (1981) Nature of the clearance of exogenous testosterone and progesterone in ejaculated bovine semen. J. Androl. 2, 205-210.

Goddard, P. \& Hill, M.J. (1972) The degradation of steroids by intestinal bacteria. IV. The aromatisation of ring A. Biochim. Biophys. Acta 280, 336-342.

Graves, C.N. \& Eiler, H. (1979) Cortisol content of semen and the effect of exogenous cortisol on the concentration of cortisol and minerals $(\mathrm{Ca}, \mathrm{Mg}, \mathrm{K}$ and $\mathrm{Na}$ ) in semen and blood plasma of bulls. Biol. Reprod. 21, 1225-1229.

Groen, M.B. \& Leemhuis, J. (1980) Synthesis of compound $\mathbf{X}$, a non steroidal constituent of female urine, and congeners. Tetrahedron Lett. 21, 50435046.

Harkis, J.M. (1973) Lignin. In Chemistry and Biochemistry of Herbage, pp. 323-373. Eds G. W. Butler \& R. W. Bailey. Academic Press, London.

Hartwell, J.L. (1976) Types of anticancer agents isolated from plants. Cancer Treat. Rep. 60, 1031-1067.

Hungate, R.E. (1966) The Rumen and its Microbes, pp. 43-48. Academic Press, New York.

Jondet, M. \& Tea, N.T. (1981) Le spermogramme et son interprétation. In Hormonologie de la Stérilité. Explorations et Thérapeutiques, pp. 223-252. Ed. R. Scholler. SEPE/FRH, Paris.

Pelter, A., Satyanarayana, P. \& Ward, R.S. (1981) A short efficient synthesis of trans-dibenzylbutyrolactones exemplified by the synthesis of di-O-methyl compound $\mathrm{X}$ (HPMF) and an anti-tumour extractive. Tetrahedron Lett. 21, 1549-1550.
Reiffsteck, A., Dehennin, L. \& Scholler, R. (1981) Concentrations d'estrone et d'estradiol-17 $\beta$ déterminées par dilution isotopique-spectrometrie de masse dans les plasmas séminaux d'homme, de taureau et de verrat. Path. Biol. 29, 335-336.

Setchell, K.D.R., Bull, R. \& Adlercreutz, H. (1980) Steroid excretion during the reproductive cycle and in pregnancy of the Vervet monkey (Cercopithecus aethiopus pygerythrus). J. Steroid Biochem. 12, 375-384.

Setchell, K.D.R., Lawson, A.M., Axelson, M. \& Adlercreutz, H. (1980) The excretion of two new phenolic compounds during the menstrual cycle and in pregnancy. In Endocrinological Cancer, Ovarian Function and Disease, pp. 207-215. Eds $\mathrm{H}$. Adlercreutz, R. D. Bulbrook, H. J. van der Molen, A. Vermeulen \& F. Sciarra. Excerpta Medica, Amsterdam.

Setchell, K.D.R., Lawson, A.M., Mitchell, F.L., Adlercreutz, H., Kirk, D.N. \& Axelson, M. (1981a) Lignans in man and animal species. Nature, Lond. 287, 740-742.

Setchell, K.D.R., Lawson, A.M., Conway, E., Taylor, N.F., Kirk, D.N., Cooley, G., Farrant, R.D., Wynn, S. \& Axelson, M. (1981b) The definitive identification of the lignans trans-2,3-bis (3'-hydroxybenzyl)- $\gamma$-butyrolactone and 2,3-bis ( $3^{\prime}$-hydroxybenzyl)-butane-1,4-diol in human and animal urine. Biochem. J. 197, 447-458.

Setchell, K.D.R., Lawson, A.M., Borriello, S.P., Harkness, R., Gordon, H., Morgan, D.M.L., Kirk, D.N., Adlercreutz, H., Anderson, L.C. \& Axelson, M. (1981c) Lignan formation in man-microbial involvement and possible roles in relation to cancer. Lancet ii, 4-7.

Stitch, S.R., Toumba, J.K., Groen, M.B., Funke, C.W., Leemhuis, J., Vink, J. \& Woods, G.F. (1980) Excretion, isolation and structure of a new phenolic constituent of female urine. Nature, Lond. 287, 738-740.

Thibier, M. \& Colchen-Bourlaud, M.A. (1972) Le choix du jeune taurillon sur sa fonction sexuelle. Elev. Insém. 127, 3-43.

Received 30 December 1981 